\title{
EFEKTIFITAS INSTRUMEN TLC TERHADAP ANGKA KEJADIAN PHLEBITIS DI RUANGAN ORCHID RS AWAL BROS PEKANBARU
}

\author{
Yulia Harmon ${ }^{1)}$, Elvi Murniasih' ${ }^{2)}$, Rachmawaty M Noer ${ }^{3)}$ \\ ${ }^{1,2,3)}$ STIKes Awal Bros Batam \\ e-mail: rachmawatymnoer1977@gmail.com, elvi.murniasih77@gmail.com
}

\begin{abstract}
ABSTRAK
Pemasangan infus termasuk salah satu prosedur medis yang paling sering dilakukan sebagai tindakan terapeutik. Terapi infus merupakan tindakan yang paling sering dilakukan pada pasien yang menjalani rawat inap sebagai jalur terapi intravena (IV), pemberian obat, cairan, dan pemberian produk darah, atau sampling darah.

Infiltrasi intravena merupakan kejadian yang sangat sering terjadi pada pasien anak. Kejadian infiltrasi infus pada pasien anak cenderung mengalami peningkatan. Jenis penelitian ini adalah eksperimen dengan rancangan pre-post perlakuan yaitu menghitung angka kejadian phlebitis sebelum dan sesudah di berikan instrumen TLC pada pasien di ruangan orchid Rumah Sakit Awal Bros Pekanbaru.

Berdasarkan hasil penelitian insiden phlebitis sebelum edukasi TLC sebanyak 15 orang dan setelah edukasi sebanyak 8 orang. Hasil uji independent $t$-test didapatkan nilai $p$ value sama dengan 0,001 ( $p$ value $<0,05)$ maka terdapat pengaruh edukasi TLC terhadap angka kejadian phlebitis diruangan Orchid Rumah Sakit Awal Bros Pekanbaru.
\end{abstract}

Kata Kunci: Plebitis, Terapi Infus

\begin{abstract}
Infusion is one of the most commonly performed medical procedures as a therapeutic measure. Infusion therapy is the procedure most often performed on patients who are hospitalized as a line of intravenous (IV) therapy, administration of drugs, fluids, and administration of blood products, or blood sampling.

Intravenous infiltration is a very common occurrence in pediatric patients. The incidence of infusion infiltration in pediatric patients tends to increase. This type of research is an experiment with a pre-post treatment design, which is to calculate the incidence of phlebitis before and after the TLC instrument was given to patients in the orchid room of Awal Bros Hospital Pekanbaru.

Based on the results of research, the incidence of phlebitis before TLC education was 15 people and after education there were 8 people. The results of the independent $t$-test showed that the $p$ value was equal to 0.001 ( $p$ value <0.05), so there was an effect of TLC education on the incidence of phlebitis in the Orchid room at Awal Bros Hospital Pekanbaru.
\end{abstract}

Keyword: Phlebitis, Infusion Therapy

\section{PENDAHULUAN}

Terapi intravena merupakan metode yang efektif untuk mensuplai cairan, elektrolit, nutrisi dan obat melalui pembuluh darah (intravascular). Terapi intravena diinstruksikan oleh dokter tetapi perawatlah yang bertanggung jawab pada pemberian dan mempertahankan terapi tersebut pada pasien. (Perry \& Potter, 2001 dalam Gayatri \& Handiyani, 2016). Pedoman 
$\begin{array}{lrr}\text { nasional } & \text { menyatakan } & \text { bahwa } \\ \text { pemindahan } & \text { infus } & \text { harus }\end{array}$

dipertimbangkan setelah dipasang lebih dari 72 jam (HPS, 2012) atau 72-96 jam

(Departemen Kesehatan, 2011) karena risiko komplikasi meningkat

(Mc.Callum, Higgins 2012).

Infiltrasi intravena merupakan kejadian yang sangat sering terjadi pada pasien anak. Kejadian infiltrasi infus pada pasien anak cenderung mengalami peningkatan. Beberapa masalah pada pemasangan iv line pada anak yang ditemukan di Rumah sakit anak di Amerika Serikat, diantaranya kesulitan dalam melihat lokasi vena, lamanya mencari lokasi insersi vena, memperhitungkan nyeri, dan kemungkinan mempertahankan iv line saat kepatenannya dipertanyakan. (Tracie Wilt Major and Tricia K. Huey, 2016).

Kejadian infiltrasi dapat terjadi karena banyak faktor seperti, pemasangan balutan, sulitnya menemukan lokasi penusukan, tingkat nyeri yang susah untuk di nilai dan ketersediaan orang tua dalam pemasangan infus sementara pemberian cairan intravena perlu diberikan. Kejadian munculnya infiltrasi pada iv line memberikan banyak efek negatif, diantaranya berdampak pada pasien sendiri, keluarga, kualitas asuhan, waktu pelayanan, pertanggung jawaban rumah sakit, sumber yang digunakan, pembayaran kembali untuk pelayanan tambahan akibat infiltrasi (Tracie Wilt Major and Tricia K. Huey, 2016).

Komplikasi phlebitis menurut Mermel et al (2009) dalam Higginson dan Parry (2011) salah satu nya adalah trombophlebitis yang disebabkan oleh thrombosis vena dan inflamasi. Adapun menurut Radne \& Putri (2016), dampak nyata pada kejadaian phlebitis yaitu bisa mengganggu hal lain diluar keluhan penyakitnya, diantaranya yaitu rasa nyaman, aktivitas dan pola tidur pasien terganggu, dikarenakan efek phlebitis bisa menyebabkan jaringan daerah vena tempat penusukan kateter intravena mengalami nyeri, bengkak dan panas. Dampak lain bagi institusi yang bersangkutan yaitu bertambahnya tugas perawat, akan memunculkan persepsi masyarakat akan kualitas pelayanan Rumah Sakit yang buruk serta adanya kemungkinan persepsi tindakan malpraktek yang dilakukan Rumah Sakit. Penelitian yang dilakukan oleh Agustini, Utomo, \& Agrina, (2014), menunjukan bahwa angka kejadian phlebitis di Rumah Sakit Awal Bros Pekanbaru sekitar 18,6\% yang sudah menampakan adanya tanda-tanda seperti bengkak disekitar tusukan jarum infus, kemerahan dan nyeri sepanjang vena.

Hasil penelitian didapatkan bahwa terdapat hubungan yang signifikan antara Letak Pemasangan Kateter Intravena dengan Kejadian Flebitis di Ruang Penyakit Dalam RSUD Ciamis Tahun 2017 Karena nilai nilai $p$ value $(0,003)<\alpha(0,05)$. Diperoleh pula nilai OR 6,909, artinya letak pemasangan kateter intravena di tangan lebih mempunyai resiko 6,909 kali untuk terjadi phlebitis di banding letak pemasangan kateter di lengan. Vena di tangan yang sering terjadi phlebitis yaitu vena radialis sebanyak 19 responden $(34,5 \%)$, vena metacarpal sebanyak 13 responden $(23,6 \%)$.

Mengingat pentingnya instrumen TLC ini dan belum pernah dilakukan di RS Awal Bros Pekanbaru tentang efektifitas instrumen TLC (Touch, Look, Compare) terhadap angka kejadian flebitis di ruangan Orchid (Pediatrik) di RS Awal Bros Pekanbaru maka penulis tertarik untuk melakukan penelitian sehingga angka kejadian phlebitis khususnya di RS Awal Bros Pekanbaru terutama di ruangan Orchid dapat diturunkan dan bahkan 
tidak ada yang mengalami phlebtis di waktu yang akan datang.

\section{METODOLOGI PENELITIAN}

Jenis penelitian ini adalah eksperimen dengan rancangan pre-post perlakuan yaitu menghitung angka kejadian phlebitis sebelum dan sesudah di berikan instrumen TLC pada pasien di ruangan orchid Rumah Sakit Awal Bros Pekanbaru

Sampel dari penelitian ini adalah seluruh pasien rawat inap yang di rawat di ruangan orchid Rumah Sakit Awal Bros Pekanbaru pada bulan Juli 2019.

Sampel yang digunakan 25 responden yang memenuhi kriteria inklusi. Tehnik pengambilan sampel yang digunakan adalah Total sampling, dimana seluruh responden yang memenuhi kriteria inklusi adalah pasien rawat inap di ruang orchid pada bulan Juli

\section{HASIL DAN PEMBAHASAN}

Berdasarkan hasil penelitian insiden phlebitis sebelum edukasi TLC sebanyak 15 orang dan setelah edukasi sebanyak 8 orang. Hasil uji independent $t$-test didapatkan nilai $p$ value sama dengan 0,001 ( $p$ value $<0,05)$ maka terdapat pengaruh edukasi TLC terhadap angka kejadian phlebitis diruangan Orchid Rumah Sakit Awal Bros Pekanbaru tahun 2019.

Berdasarkan hasil pengumpulan data terhadap 25 responden pada tanggal $01 \mathrm{Juli}$ 2019 sampai 15 Juli 2019 dan setelah data diolah, maka peneliti akan mebahas mengenai Efektifitas Instrumen TLC (Touch, Look, Compare) terhadap Kejadian Phlebitis di ruangan Orchid RS Awal Bros Pekanbaru. Berdasarkan data distribusi responden menurut usia didapatkan mayoritas responden berusia 0-5 tahun (56\%). Menurut Anggita (2018), anak dengan usia muda dan para lansia merupakan kelompok yang memiliki pembuluh darah vena yang rapuh.

Pembuluh darah yang rapuh pada anakanak saat pemasangan iv kateter menyebabkan vena mudah pecah. Hal ini dikarenakan fungsi tubuh baik secara fisik, biologis, psikologis dan sosial yang belum optimal (Lubis \& Widiastuti, 2019).

\section{KESIMPULAN}

Setelah dilakukan penelitian tentang "Pengaruh Edukasi TLC (Touch, Look, Campare) terhadap Angka Kejadian Phlebitis di Ruangan Orchid Rumah Sakit Awal Bros Pekanbaru" dapat disimpulkan:

1. Angka kejadian phlebitis sebelum diberikan instrumen TLC sebanyak 15 responden atau $60 \%$ dari 25 responden.

2. Angka kejadian phlebitis setelah diberikan instrumen TLC sebanyak 8 responden atau $32 \%$ dari 25 responden.

3. Berdasarkan hasil penelitian insiden phlebitis sebanyak 15 orang. Setelah diterapkan monitoring lembar TLC insiden phlebitis menurun menjadi 8 orang. Hasil uji independent t-test didapatkan nilai $p$ value sama dengan $0,001$ ( $p$ value $<0,05)$ maka terdapat pengaruh penyuluhan terhadap angka kejadian phlebitis diruangan orchid rumah sakit Awal Bros Pekanbaru.

\section{DAFTAR PUSTAKA}

Asrin, Triyanto, E., \& Setyoupoyo. (2006).

Analisis faktor-faktor yang berpengaruh terhadap kejadian phlebitis di RSUD

Purbalingga. Jurnal keperawatan Soedirman volume 1 no 1.

Frakes, E., \& Jililan, R. (2018). Take my IV out! Partnering to reduce PIV Extravacation harm.

Hasanah, O., Novayelinda, R., \& Maifera, I. (2017 ). MENURUNKAN DERAJAT FLEBITIS AKIBAT TERAPI INTRAVENA PADA ANAK DENGAN KOMPRES ALOE VERA: STUDI PILOT. Jurnal Keperawatan Indonesia, hal 24-31. 
Lubis, E., \& Widiastuti. (2019). HUBUNGAN

FAKTOR - FAKTOR YANG

MEMPENGARUHI PHLEBITIS

TERHADAP TERJADINYA PLEBITIS.

VOL 4 No 1.

Pearson. (1996). Guideline for prevention of intravasculer devicerelated infection.

American journal of infection control.

Sumara, R. (2017). Hubungan lokasi terapi intravenus dengan kejadian phlebitis.

Jurnal keperawatan muhammadiyah, 130-131.

Walyunah, Nurrahmah, E., \& Mulyono, S.

(2013). PENGETAHUAN PERAWAT

TENTANG TERAPI INFUS

MEMENGARUHI KEJADIAN

PHLEBITIS DAN KENYAMANAN

PASIEN. Jurnal Keperawatan Indonesia

Volume 16 No. 2 . 